\section{Residential radon and lung cancer: a cohort study in Galicia, Spain}

\author{
Radón residencial y cáncer de pulmón: un \\ estudio de cohorte en Galicia, España
}

\author{
Radônio residencial e câncer de pulmão: um \\ estudo de coorte na Galícia, Espanha
}

\author{
Raquel Barbosa-Lorenzo 1,2 \\ Alberto Ruano-Ravina 1,3 \\ Sara Cerdeira-Caramés 4 \\ Mónica Raíces-Aldrey 1 \\ Juan M. Barros-Dios 1,3
}

doi: 10.1590/0102-311X00189415

\begin{abstract}
Case-control studies show an association between residential radon and lung cancer. The aim of this paper is to investigate this association through a cohort study. We designed an ambispective cohort study using the Galician radon map, Spain, with controls drawn from a previous case-control study. Subjects were recruited between 2002 and 2009. The data were cross-checked to ascertain lung cancer incidence and then analysed using a Cox regression model. A total of 2,127 subjects participated; 24 lung cancer cases were identified; $76.6 \%$ of subjects were drawn from the radon map. The adjusted hazard ratio was 1.2 (95\% CI: 0.5-2.8) for the category of subjects exposed to $50 \mathrm{~Bq} / \mathrm{m}^{3}$ or more. This risk rose when subjects from the case-control study were analyzed separately. In conclusion, we did not observe any statistically significant association between residential radon exposure and lung cancer; however, it appears that with a sample of greater median age (such as participants from the case-control study), the risk of lung cancer would have been higher.

Radon; Environmental Carcinogens; Radiation Exposure; Lung Neoplasms
\end{abstract}

\author{
Correspondence \\ A. Ruano-Ravina \\ Departamento de Medicina Preventiva y Salud Pública, \\ Facultad de Medicina, Universidad de Santiago de Compostela. \\ Rúa de San Francisco s/n., 15782, Santiago de \\ Compostela, España. \\ alberto.ruano@usc.es \\ 1 Facultad de Medicina, Universidad de Santiago de Compostela, \\ Santiago de Compostela, España. \\ 2 Hospital Comarcal de Monforte de Lemos, Monforte de Lemos, \\ España. \\ 3 Centro de Investigación Biomédica en Red Epidemiología y \\ Salud Pública, Madrid, España. \\ 4 Consellería de Sanidade, Xunta de Galicia, Santiago de \\ Compostela, España.
}




\section{Introduction}

Lung cancer is the leading cause of cancer-related death worldwide, with 1.8 million estimated deaths in 2012. It accounts for $13 \%$ of all cancer-related cases and $19.4 \%$ of all cancer-related deaths 1 .

In Europe, these figures hold constant. Lung cancer accounts for $20 \%$ of total cancer-related deaths 2. It is the leading cause of cancer-related death among men and the third greatest cause of mortality among women 2 . Aside from this high incidence, it should be stressed that 5 -year survival is only $13 \% 3$.

The principal risk factor for lung cancer is smoking, followed by residential radon, which is the leading cause of lung cancer among those who have never smoked. However, this evidence comes mainly from case-control studies.

Radon is a colorless, odorless and tasteless gas which appears in the $238 \mathrm{U}$ chain of decay. Radon's short half-life progeny emit alpha particles which impact the pulmonary epithelium and cause alterations at a molecular level. This process can eventually cause cancer 4 .

While indoor concentrations of radon depend largely on the $238 \mathrm{U}$ content of the subsoil on which the respective building stands 4 , they are also influenced by other factors. These factors include characteristics of the respective dwelling (cracks, hairline cracks, insulation), the dwelling's construction materials, and its age 5. It is thus important to monitor residential radon in order to ensure that mitigation measures can be implemented in any dwelling with high radon concentrations.

The U.S. Environmental Protection Agency (USEPA) 6 recommends that no dwelling exceed radon concentrations of 148 becquerels per cubic metre $\left(\mathrm{Bq} / \mathrm{m}^{3}\right)$, while the World Health Organization (WHO) ${ }^{4}$ has recently lowered this recommendation to $100 \mathrm{~Bq} / \mathrm{m}^{3}$. Nevertheless, in Galicia, Spain, the subject area of this study, $18.5 \%$ of all dwellings exceed $200 \mathrm{~Bq} / \mathrm{m}^{3}$, which clearly indicates that this part of Spain is a high radon-emission area 7.

Spanish legislation only regulates radon exposure with respect to workers. Most countries have radon exposure maps, which are useful for planning solutions in the building sector depending on the geographical area 8 and also for public health awareness campaigns. Such maps may serve as important instruments for studying the effects of radon on health, as they can be used to form cohorts of exposed and unexposed subjects.

Most of the available studies on radon and lung cancer in the general population have used a case-control design, and very few have used a cohort design. To our knowledge, there has been only one cohort study on residential radon and lung cancer risk with individual measurements taken at participants' homes, but it had a small sample size 9 .

The aim of this paper is to investigate the association between residential radon and lung cancer through a cohort study.

\section{Materials and methods}

An ambispective cohort study was designed using individuals drawn from the Galician radon map 5,10 and controls from a previous case-control study ${ }^{11}$. Subjects were recruited across the period 2002-2009.

The Galician radon map is a cross-sectional study with a random selection of participants using a stratified and multistage cluster sampling, using a geographic unit in the first step ("shire") and municipality as the second step, with weights proportional to the population of the municipality. The sampling was defined for each municipality that had at least two radon measurements. The main objective of the Galician radon map is to ascertain specific areas of high residential radon exposure and thereby implement prevention activities in these areas. The only inclusion criteria for participants were acceptance to participate and aged over 18 .

In this research project a trained technician travelled to the selected dwellings to install the radondetection devices. During that time, a structured interview with participants was undertaken in order to retrieve information regarding the participants' habits (age, tobacco consumption, occupation, length of time living in the dwelling) and also regarding the house characteristics (construction materials, age of the dwelling). The study started in 2002 and is being constantly updated with new mea- 
surements. We only included radon measurements up to 2009 in order to have a minimum follow-up time since the radon measurement.

Initially, the Galician radon map was designed to include approximately 3,000 participants but due to inconsistencies and refusals to participate we included 1,632 participants up to 2009. The sample size was a convenience sample and these participants adequately represent the Galician population (both geographically and by population density). We therefore decided to add participants from the control group from a case-control study 11 to enlarge this sample size. The case-control study was conducted in the same area, and with the goal of ascertaining the influence of residential radon on the outcome of lung cancer. Individuals who had a previous history of cancer, were under 30 years of age, or had lived less than five years in their current home were excluded. Participants in the hospital control group were selected from individuals who had undergone scheduled surgical interventions unrelated to smoking. For the purposes of our cohort study, only participants in the control group were included. These participants were selected using sampling based on frequency of sex and age with respect to cases in the case-control study. They were then joined to the cohort in order to increase the study's sample size and statistical power. There was no duplication of cases between both studies.

All study protocols were approved by the Galician Clinical Ethics Research Committee (REF 2004/108) and study participants were informed by letter of their radon results. In cases where the results were above reference levels, the letter also contained information regarding what to do. The main mitigation measures proposed were sealing of cracks and joints in the walls and basement along with proper housing ventilation.

\section{Constitution of the cohort and follow-up period}

The date of inclusion in the cohort was the date on which the participant had been included in either of the two studies and the radon detector had been installed in his or her home. The period prior to this date - included as pre-measurement follow-up time - was the length of time during which the participant had resided in that same dwelling. The post-measurement period extended until the end of follow-up or the occurrence of the event of interest (date of diagnosis of lung cancer), or alternatively, a censored time (death due to any other cause, change of address to a point outside Galicia or follow-up until 31 December 2012).

\section{Radon measurement}

In both studies, the subjects received instructions designed to ensure that measurement would be taken in conditions conducive to obtaining quality results. The detectors were placed in the room in which the participant spent the majority of his or her time for a period of 3 to 6 months.

Measurements were taken using alpha-track-type CR-39 detectors and were then analyzed using a Radosys (Radosys Group, Budapest, Hungary) device at the Galician Radon Laboratory (University of Santiago de Compostela). This Radosys device has been used in intercomparison exercises sponsored by the Nuclear Safety Commission and the University of Cantabria with excellent results 12,13,14. Seasonal adjustment was used to determine the residential radon concentrations.

\section{Data-collection at date of inclusion in cohort}

The information collected at baseline included lifestyle-related data, with special stress laid on smoking habits, characteristics of the dwelling, and duration of participants' residence at the given location.

\section{Ascertainment of cohort subjects' vital status}

At the beginning of 2013, each individual's status was ascertained by means of three data sources, i.e., the Galician mortality registry, protocoled calls to participants, and electronic medical records.

The calls were made by a trained interviewer to obtain information about participants' vital status, development of any cancer since the detector's installation, smoking habit since the first survey, structural alterations to the dwelling, and change of address. A check was run on the electronic 
medical records, in order to know whether participants had developed any type of cancer, their vital status and, in the event of death, the underlying cause. The Galician Mortality Registry databases were cross-checked to corroborate the study subjects' vital status.

\section{Statistical analysis}

Data were analyzed using a multivariate Cox regression model in which the dependent variable was development of lung cancer. Residential radon concentration was used as the independent variable in two categories, with the cut-off point set at $50 \mathrm{~Bq} / \mathrm{m}^{3}$. The adjustment variables were sex, age and tobacco use. Tobacco use was calculated on the basis of two surveys (initial and final) and measured in pack-years (packs smoked per year). The time-scale used was duration (years) of follow-up for each participant. The results were expressed as hazard ratios (HRs) with a $95 \%$ confidence interval (95\%CI). Any subject who developed any non-pulmonary cancer during follow-up was counted as lost to follow-up. Four other models were fitted, with each restricted as follows: men only (due to the low number of observed cases in women); only individuals who had been living in the same dwelling for more than 25 years; only persons who were over the age of 50 years at the date of their inclusion in the cohort; and lastly, according to participants' study of origin (Galician radon map and controls from the case-control study). Crude and adjusted models were fitted for each of these categories. All analyses were performed using version 21 of the SPSS computer software package (SPSS Inc., Chicago, USA).

\section{Results}

A total of 2,127 subjects participated in the cohort study; 24 cases of lung cancer were identified (cumulative incidence of 1.1\%); mean duration of follow-up was 30.2 years, with a total of 64,189 years at risk. The mean post-measurement follow-up time was 6.7 years. $76.6 \%$ of subjects were drawn from the Galician radon map and the remainder were controls from the case-control study.

Figure 1 shows the flow diagram on the study subjects. We excluded only two individuals (other than participants who developed non-pulmonary cancer) because we did not know their birth dates. For the remaining subjects, there were no excluded data because we used three data sources to avoid losing participants.

Table 1 provides a brief description of the initial cohort and lung cancer cases. At the date of entry into the study, more than $50 \%$ of the subjects from the initial cohort were aged 51 or older and $57.4 \%$ were men.

$23.4 \%$ of dwellings belonged to subjects participating in the initial cohort and $20.8 \%$ of dwellings belonged to cases exceeding the $148 \mathrm{~Bq} / \mathrm{m}^{3}$ threshold. Mean duration of residence in the monitored dwellings was 30 years. In terms of smoking habits, $54 \%$ of cohort subjects were never-smokers as opposed to $23 \%$ of participants that smoked. With regard to the response rate, $39.7 \%$ of subjects failed to respond to the telephone interview, mostly due to not answering the call. $91.7 \%$ of participants' clinical records were reviewed.

Table 2 shows the characteristics of the cohort subjects according to their respective studies of origin. The incidence of lung cancer was $0.8 \%$ for the radon-map subjects and $2.2 \%$ for the case-control study. The distribution of subjects by age and sex were different in both subsamples.

Table 3 shows lung cancer risks. The adjusted HR for lung cancer for those exposed to $50 \mathrm{~Bq} / \mathrm{m}^{3}$ or more was 1.2 (95\%CI: $0.5-2.8$ ) with respect to those exposed to less than $50 \mathrm{~Bq} / \mathrm{m}^{3}$. Similar results were observed when the analysis was restricted to subjects who had resided for 25 years or more in the monitored dwelling, and to subjects aged 50 years or over at baseline. The risk increased but continued to be non-significant when the analysis was restricted to men alone, with an HR of 1.4 (95\%CI: $0.5-3.6$ ) for those exposed to over $50 \mathrm{~Bq} / \mathrm{m}^{3}$. When the analysis was restricted to subjects' type of study, it yielded an adjusted HR for the category of $50 \mathrm{~Bq} / \mathrm{m}^{3}$ or more of 0.5 (95\%CI: 0.1-1.6) for radon-map subjects and an adjusted HR of 1.9 (95\%CI: 0.8-7.3) for participants from the casecontrol study. 
Flow diagram of the study subjects.

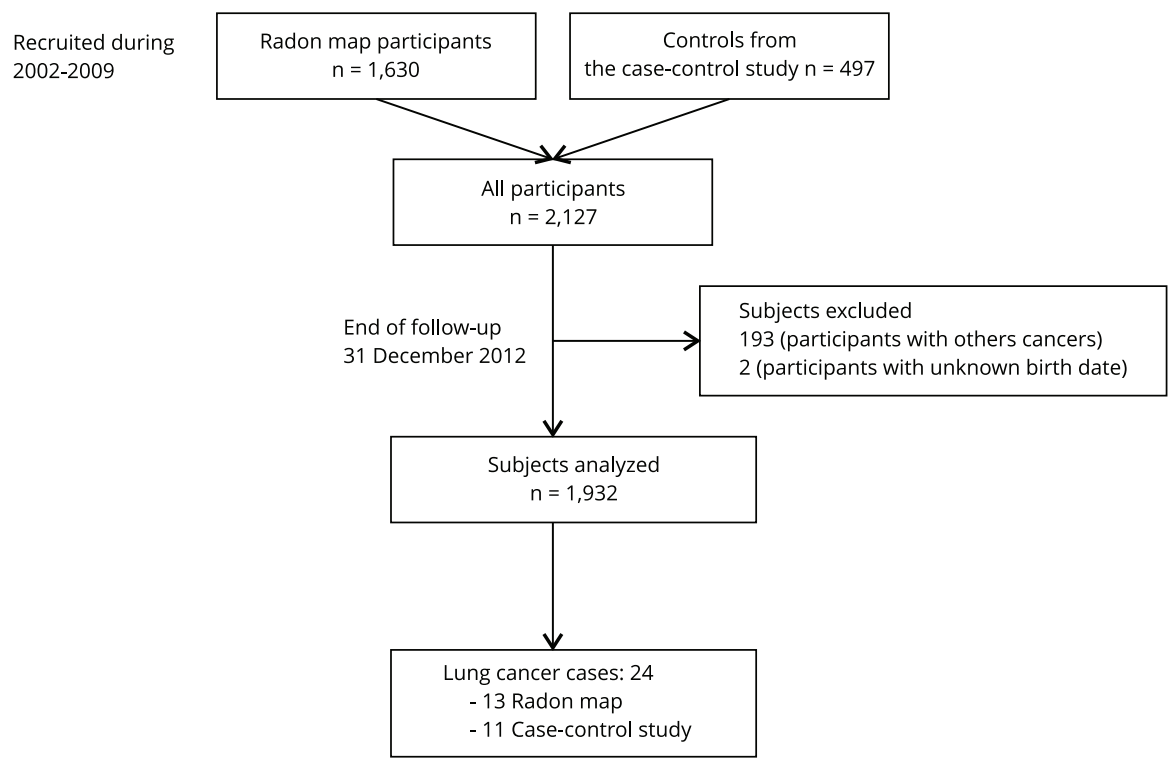

\section{Discussion}

These results show a positive, though non-statistically significant, association between lung cancer and exposure to residential radon for individuals exposed to more than $50 \mathrm{~Bq} / \mathrm{m}^{3}$. This effect is slightly more marked when the analysis is restricted to men but does not change appreciably when analyzing individuals who resided in the monitored dwellings for 25 years or more, or individuals aged 50 years or over at the date of radon measurement. A considerable increase in lung cancer risk is, however, observed when the analysis is restricted to subjects having a higher mean age (controls from the case-control study). While this risk does not attain statistical significance, it nevertheless comes close ( $\mathrm{HR}=1.9 ; 95 \% \mathrm{CI}$ : 0.8-7.3), though there is only a total of 497 subjects and 11 cases in this subgroup. To our knowledge, this is the second cohort study ever conducted on residential radon and lung cancer to have measured radon concentrations in the dwellings of all participants (as opposed to using a municipal or some other type of estimate).

Our results did not show any statistically significant association between residential radon exposure and lung cancer. This could be mainly due to the inclusion criteria of age for participants from the Galician radon map, who were selected to represent the Galician population. In any case, when we repeated the analysis including only participants older than 36 , the results did not change.

In 2008, our research group published a cohort study which found a strong association between residential radon and lung cancer $(\mathrm{RR}=6.6$; 95\%CI: $1.2-38.0)$ for levels over $148 \mathrm{~Bq} / \mathrm{m}^{3}$, with the limitation of having a sample size of only 211 subjects 9 . The principal differences between the two studies lie in the mean age of the subjects included and the post-measurement time. In the first cohort the mean age was 56.9 years (6.1 years older than that of the current cohort), and the mean postmeasurement follow-up time was 12 years (5.3 years longer than that of the current cohort). This would favor the appearance of the association, because the follow-up time in the present cohort may not be sufficient to induce lung cancer. Half the members of the current cohort were aged 50 years or under at the date of recruitment. Another aspect that might have influenced the lack of association 
Description of cohorts and incident cases.

\begin{tabular}{|c|c|c|}
\hline & $\begin{array}{c}\text { Initial cohort } \\
\text { n (\%) }\end{array}$ & $\begin{array}{l}\text { Cases } \\
\text { n (\%) }\end{array}$ \\
\hline Total & $2,127(100.0)$ & $24(1.1)$ \\
\hline \multicolumn{3}{|l|}{ Age (years) * } \\
\hline$<36$ & 455 (21.4) & $0(0.0)$ \\
\hline $36-50$ & $574(27.1)$ & $1(4.2)$ \\
\hline $51-65$ & $629(29.6)$ & $12(50.0)$ \\
\hline$>65$ & $464(21.9)$ & $11(45.8)$ \\
\hline \multicolumn{3}{|l|}{ Sex } \\
\hline Male & $1,220(57.4)$ & $20(83.3)$ \\
\hline Female & $907(42.6)$ & $4(16.7)$ \\
\hline \multicolumn{3}{|l|}{ Exposure to radon $\left(\mathrm{Bq} / \mathrm{m}^{3}\right)$} \\
\hline Mean & 110.2 & 108.3 \\
\hline Median & 68.0 & 61.5 \\
\hline Minimum-maximum & $6-1,590$ & $15-468$ \\
\hline 25th-75th percentile & $38.0-142.0$ & $35.25-125.0$ \\
\hline \multicolumn{3}{|l|}{ Smoking habit ** } \\
\hline Never smoker & $1,121(53.6)$ & $5(22.7)$ \\
\hline 1-40 pack-years & $721(34.5)$ & $5(22.7)$ \\
\hline$>40$ pack-years & $248(11.9)$ & $12(54.6)$ \\
\hline \multicolumn{3}{|c|}{ Time of residence in dwelling (years) $* \star *$} \\
\hline$<10$ & $150(7.1)$ & $1(4.2)$ \\
\hline $10-25$ & $847(39.8)$ & $5(20.8)$ \\
\hline$>25$ & $1,128(53.1)$ & $18(75.0)$ \\
\hline \multicolumn{3}{|l|}{ Educational level \# } \\
\hline No formal education & $99(5.0)$ & $4(19.0)$ \\
\hline Primary & $949(47.8)$ & $13(61.9)$ \\
\hline Secondary & $457(23.0)$ & $3(14.3)$ \\
\hline University & $480(24.2)$ & $1(4.8)$ \\
\hline
\end{tabular}

* Information missing for 5 subjects of the initial cohort;

** Information missing for 37 subjects of the initial cohort, 2 of whom were cases;

*** Information missing for 2 subjects of the initial cohort;

\# Information missing for 142 subjects, 3 of whom were cases.

observed is that subjects with high concentrations (and there were some who had concentrations even higher than $1,000 \mathrm{~Bq} / \mathrm{m}^{3}$ ) did not develop lung cancer precisely because a relatively short induction period was allowed.

Both studies were based on individual measurements (for each dwelling) of residential radon, unlike the studies having the same design and shown in Table 4 15,16,17. In most of the latter studies, radon concentrations were obtained by estimation using mathematical models, or had measures that were directly attributable to the mean concentrations of radon in the participants' county of residence, whereas in our study, individualized radon concentrations were obtained for each dwelling 9,15,16,17.

All the published cohort studies report an association of different magnitudes, except for that of Bräuner et al. 16, which also observed no effect. The results of our study are comparable to those of Bräuner et al. 16, who observed an adjusted HR for lung cancer of 1.04 (95\%CI: 0.69-1.56) for every $100 \mathrm{~Bq} / \mathrm{m}^{3}$ of increase in radon concentrations. When the analysis was restricted to non-smokers, the HR rose to 1.67 (95\%CI: 0.69-4.04) 16. In our study, the analysis could not be restricted to 
Table 2

Description of cohort subjects according to type of study.

\begin{tabular}{|c|c|c|}
\hline & $\begin{array}{c}\text { Radon map } \\
\text { n (\%) }\end{array}$ & $\begin{array}{c}\text { Case-control study } \\
\text { n (\%) }\end{array}$ \\
\hline Total & $1,630(76.6)$ & $497(23.4)$ \\
\hline Incidence of lung cancer & $13(0.8)$ & $11(2.2)$ \\
\hline \multicolumn{3}{|l|}{ Age (years) } \\
\hline Mean & 47.0 & 63.3 \\
\hline Median & 46 & 63 \\
\hline 25th-75th percentile & $34-59$ & $55-71$ \\
\hline \multicolumn{3}{|l|}{ Sex } \\
\hline Male & $786(48.2)$ & $435(87.3)$ \\
\hline Female & $844(51.8)$ & $63(12.7)$ \\
\hline \multicolumn{3}{|l|}{ Exposure to radon $\left(\mathrm{Bq} / \mathrm{m}^{3}\right)$} \\
\hline Arithmetic mean & 117.4 & 86.6 \\
\hline Median & 70.5 & 63.0 \\
\hline 25th-75th percentile & $38.0-155.0$ & $39.0-109.0$ \\
\hline \multicolumn{3}{|l|}{ Smoking habit * } \\
\hline Never smoker & $901(56.5)$ & $220(44.5)$ \\
\hline 1-40 pack-years & $570(35.7)$ & $151(30.6)$ \\
\hline$>40$ pack-years & $125(7.8)$ & $123(24.9)$ \\
\hline \multicolumn{3}{|c|}{ Time of residence in dwelling (years) ** } \\
\hline$<10$ & $143(8.8)$ & $7(1.4)$ \\
\hline $10-25$ & $689(42.3)$ & $158(31.8)$ \\
\hline$>25$ & 796 (48.9) & $332(66.8)$ \\
\hline
\end{tabular}

* Information missing for 34 radon-map subjects and 3 case-control study subjects;

** Information missing for 2 radon-map subjects.

non-smokers, because there were only five cancer cases in that category. Turner et al, however, found a significant association. A recent study reported that never-smokers have over twice the risk of lung cancer if they are exposed to more than $200 \mathrm{~Bq} / \mathrm{m}^{3}$, as compared to exposures of less than $50 \mathrm{~Bq} / \mathrm{m}^{3}$, which would appear to indicate that the radon concentration required to cause lung cancer in neversmokers might be somewhat higher 18 . Turner's et al. 15 study reported a $15 \%$ increase $(95 \% \mathrm{CI}$ : 1.01-1.31) in lung cancer mortality for every $100 \mathrm{~Bq} / \mathrm{m}^{3}$ of increase in radon. A study conducted by Tomásek et al. 17 showed an excess of relative risk of 0.10 (95\%CI: 0.04-0.17) for each 100Bq/ $\mathrm{m}^{3}$-increase in exposure to radon progeny, the methodology used differed from the other studies.

Very few general-population cohort studies have addressed this topic, and those that have been published display limitations. On the other hand, many case-control studies have analyzed the association between residential radon and risk of lung cancer; and, while these have been extremely heterogeneous in their methods, most nonetheless report finding a higher risk correlating with an increase in exposure. The association between residential radon and lung cancer has been reinforced by the results yielded by a joint analysis of studies. A European pooling concluded that the risk of lung cancer rose by $16 \%(95 \% \mathrm{CI}: 1.05-1.31)$ for every $100 \mathrm{~Bq} / \mathrm{m}^{3}$-increase in residential radon concentrations in a study with over 21,000 participants 19. In this same year, Krewski et al. 20 also performed a pooling of North American case-control studies, with over 8,000 subjects, observing an $11 \%$ rise (95\%CI: 1.00-1.28) in risk of lung cancer for each $100 \mathrm{~Bq} / \mathrm{m}^{3}$-increase in radon.

We have chosen $50 \mathrm{~Bq} / \mathrm{m}^{3}$ to compare our results with two previous works published by us using the same reference category 11,18 . This reference category is also intuitive because it is half the reference action level recommended by WHO and one third of the USEPA action level $\left(148 \mathrm{~Bq} / \mathrm{m}^{3}\right)$. 
Hazard ratios (HR) of lung cancer due to exposure to residential radon.

\begin{tabular}{|c|c|c|c|c|}
\hline & \multicolumn{2}{|c|}{ Crude model } & \multicolumn{2}{|c|}{ Adjusted model * } \\
\hline & $\begin{array}{l}\text { Cases, cohort } \\
\text { subjects }\end{array}$ & HR $(95 \% \mathrm{Cl})$ & $\begin{array}{l}\text { Cases, cohort } \\
\text { subjects }\end{array}$ & $\mathrm{HR}(95 \% \mathrm{Cl})$ \\
\hline \multicolumn{5}{|l|}{ All subjects } \\
\hline$<50 \mathrm{~Bq} / \mathrm{m}^{3}$ & 8,697 & 1.0 & 8,686 & 1.0 \\
\hline$\geq 50 \mathrm{~Bq} / \mathrm{m}^{3}$ & 16,1235 & $1.1(0.5-2.6)$ & 14,1214 & $1.2(0.5-2.8)$ \\
\hline \multicolumn{5}{|l|}{ Men only } \\
\hline$<50 \mathrm{~Bq} / \mathrm{m}^{3}$ & 6,378 & 1.0 & 6,371 & 1.0 \\
\hline$\geq 50 \mathrm{~Bq} / \mathrm{m}^{3}$ & 14,700 & $1.4(0.5-3.5)$ & 12,684 & $1.4(0.5-3.6)$ \\
\hline \multicolumn{5}{|c|}{ Subjects who had resided 25 years or more in same dwelling } \\
\hline$<50 \mathrm{~Bq} / \mathrm{m}^{3}$ & 6,383 & 1.0 & 6,374 & 1.0 \\
\hline$\geq 50 \mathrm{~Bq} / \mathrm{m}^{3}$ & 12,667 & $1.1(0.4-3.0)$ & 10,654 & $1.1(0.4-3.1)$ \\
\hline \multicolumn{5}{|c|}{ Subjects aged 50 years or over at the start of the study } \\
\hline$<50 \mathrm{~Bq} / \mathrm{m}^{3}$ & 8,362 & 1.0 & 8,356 & 1.0 \\
\hline$\geq 50 \mathrm{~Bq} / \mathrm{m}^{3}$ & 16,611 & $1.1(0.5-2.7)$ & 14,600 & $1.1(0.5-2.7)$ \\
\hline \multicolumn{5}{|c|}{ Radon-map subjects } \\
\hline$<50 \mathrm{~Bq} / \mathrm{m}^{3}$ & 5,541 & 1.0 & 5,532 & 1.0 \\
\hline$\geq 50 \mathrm{~Bq} / \mathrm{m}^{3}$ & 8,980 & $0.8(0.3-2.4)$ & 6,960 & $0.5(0.1-1.6)$ \\
\hline \multicolumn{5}{|c|}{ Controls from the case-control study } \\
\hline$<50 \mathrm{~Bq} / \mathrm{m}^{3}$ & 3,156 & 1.0 & 3,154 & 1.0 \\
\hline$\geq 50 \mathrm{~Bq} / \mathrm{m}^{3}$ & 8,255 & $1.9(0.5-7.1)$ & 8,254 & $1.9(0.8-7.3)$ \\
\hline
\end{tabular}

95Cl: 95\% confidence interval.

* Adjusted model for sex, age and tobacco use.

As of yet, the biological action mechanism of alpha radiation has not been completely elucidated. Research has focused on studying the probable signaling pathways affected in pulmonary carcinogenesis. One of the most widely studied genes is P53, nevertheless the results are not conclusive 21,22. However, an association has been found between deletion of the GSTM1 and GSTT1 genes and risk of lung cancer caused by exposure to radon 23 .

Our study has a number of advantages. Comprehensive follow-up was conducted using three different data sources, allowing us to ascertain subjects' vital status at the end of the study and, in most instances, confirm the information obtained from the respective data sources. Another important advantage of this study was that subjects' smoking habits could be considered pre- and post-measurement, as this information was collected in both the initial survey and the final telephone calls. Furthermore, the study area, Galicia, has the advantage of being an area with high radon concentrations, which makes it a natural experiment site and facilitates dose-response analysis. With regards to any possible selection bias, we feel that one was not present because the sampling technique allowed for random selection and because the resulting participants were representative of the Galician population. Lastly, the Galician people tend to live in the same dwelling for a long period of time. For example, 53\% of our study sample had resided in the monitored dwelling for more than 25 years. These results are in line with earlier studies undertaken in the same area 24 . All this goes to simplify the task of attributing lung cancer to residential radon.

This study also has important limitations, the main one being the characteristics of the sample, as the study was not initially conceived as a cohort design for measuring the causal association between residential radon and lung cancer. As a consequence, the age of the participants was lower than would have been desirable, with close to $50 \%$ of subjects being below the age of 50 years at the date of the survey. Age is closely related to cumulative lifetime tobacco use and duration of residence in the same dwelling. Therefore, if these variables in the Galician radon-map subjects and the control-participants 


\section{Table 4}

Characteristics of reported studies with a cohort design.

\begin{tabular}{|c|c|c|c|c|c|c|}
\hline Author/Year & Place & $\begin{array}{l}\text { Sample size/ } \\
\text { Cases }\end{array}$ & $\begin{array}{c}\text { Radon } \\
\text { measures }\end{array}$ & Analysis & $\begin{array}{l}\text { Median } \\
\text { radon }\end{array}$ & Results \\
\hline Tomásek et al. 17/2001 & $\begin{array}{c}\text { Czech } \\
\text { Republic }\end{array}$ & $\begin{array}{c}\text { Approximately } \\
12,000 / 173\end{array}$ & $\begin{array}{c}\text { Individuals + } \\
\text { municipal means }\end{array}$ & $\begin{array}{l}\text { Relative risk model } \\
\text { with observed/ } \\
\text { expected deaths }\end{array}$ & $\begin{array}{c}312-324 \mathrm{~Bq} / \mathrm{m}^{3} \\
\text { (mean) }\end{array}$ & $\begin{array}{c}\text { Excess of relative risk } \\
\text { (ERR) for every increase } \\
\text { of } 100 \mathrm{~Bq} / \mathrm{m}^{3}, 0.102 \\
(95 \% \mathrm{Cl}: 0.039-0.168)\end{array}$ \\
\hline $\begin{array}{l}\text { Ruano-Ravina } \\
\text { et al. 9/2009 }\end{array}$ & Galicia (Spain) & $241 / 5$ & $\begin{array}{l}\text { Detectors in each } \\
\text { dwelling }\end{array}$ & $\begin{array}{l}\text { Logistic regression } \\
\text { without adjustment }\end{array}$ & $52 \mathrm{~Bq} / \mathrm{m}^{3}$ & $\begin{array}{l}\text { Relative risk (RR) } 6.6 \\
\quad(95 \% \mathrm{Cl}: 1.2-38.0)\end{array}$ \\
\hline Turner et al. 15/2011 & $\begin{array}{c}\text { USA and } \\
\text { Puerto Rico }\end{array}$ & $811,961 / 3,493$ & Ecological & $\begin{array}{l}\text { Adjusted Cox } \\
\text { regression }\end{array}$ & $41.4 \mathrm{~Bq} / \mathrm{m} 3$ & $\begin{array}{c}\text { Hazard ratio }(\mathrm{HR}) \\
\text { adjusted for every } \\
\text { increase of } 100 \mathrm{~Bq} / \mathrm{m}^{3} \text {, } \\
1.15(95 \% \mathrm{Cl} \text { : } \\
1.01-1.31)\end{array}$ \\
\hline Bräuner et al. 16/2012 & Denmark & $52,692 / 589$ & $\begin{array}{l}\text { Validated } \\
\text { regression } \\
\text { model that } \\
\text { estimates radon } \\
\text { concentrations }\end{array}$ & $\begin{array}{l}\text { Adjusted Cox } \\
\text { regression }\end{array}$ & $35.8 \mathrm{~Bq} / \mathrm{m}^{3}$ & $\begin{array}{c}\text { Adjusted incidence rate } \\
\text { ratio (IRR) } 1.04(95 \% \mathrm{Cl} \text { : } \\
0.69-1.56)\end{array}$ \\
\hline
\end{tabular}

from the case-control study are compared, it will be seen that the median age was 17 years higher for the controls included, and that there were 17\% more heavy smokers and $18 \%$ more individuals who had lived for more than 25 years in the same dwelling among the controls. In addition, lung cancer incidence among the control group was more than double that of radon-map subjects: while the subsample of control-participants points to statistical significance, this is not so in the case of the radon-map subjects, though there were only 11 cases in this category. Another important study limitation lies in the fact that other lung-cancer risk factors, such as occupation or exposure to ambient tobacco smoke, could not be considered. Other studies indicate that both variables do not act as confounding factors 16 .

In conclusion, we did not observe any statistically significant association between residential radon exposure and lung cancer. But it seems that with a sample of higher median age (such as subject of case-control study) the risks obtained would have been greater. 


\section{Contributors}

A. Ruano-Ravina designed the research and interpreted the results. R. Barbosa-Lorenzo, S. CerdeiraCaramés, M. Raíces-Aldrey and J. M. Barros-Dios extracted the information. All authors wrote the paper and analyzed the results. All authors gave important intellectual insights to the study and approved the final version of the manuscript. A. Ruano-Ravina is the guarantor of the paper.

\section{Acknowledgments}

This work was supported by the Carlos III Institute of Health, Ministry of Science \& Innovation under grant PI10/00296 and PI03/1248. Galician Regional Authority (Xunta de Galicia) under grant PGIDT01MAM20801PR. Part of this work has been performed during a Fulbright grant for Senior Researchers awarded to Alberto Ruano-Ravina at Brown University (Providence, Rhode Island, USA) (REF PRX14/00365). This grant is awarded by the US Department of State in collaboration with the Spanish Ministry of Education. This paper forms part of Raquel Barbosa-Lorenzo's doctoral thesis. We are grateful to Daniel Bromberg, for having edited the manuscript.

\section{References}

1. International Agency for Research on Cancer. GLOBOCAN 2012: estimated cancer incidence mortality and prevalence worlwide in 2012. http://globocan.iarc.fr/Pages/ fact_sheets_population.aspx (accessed on 15/ Nov/2015).

2. Ferlay J, Steliarova-Foucher E, Lortet-Tieulent J, Rosso S, Coebergh JWW, Comber H, et al. Cancer incidence and mortality patterns in Europe: estimates for 40 countries in 2012. Eur J Cancer 2013; 49:1374-403.

3. De Angelis R, Sant M, Coleman MP, Francisci S, Baili P, Pierannunzio D, et al. Cancer survival in Europe 1999-2007 by country and age: results of EUROCARE-5: a population-based study. Lancet Oncol 2014; 15:23-34.
4. Wold Health Organization. WHO handbook on indoor radon: a public health perspective. Geneva: World Health Organization; 2009.

5. Barros-Dios JM, Ruano-Ravina A, GasteluIturri J, Figueiras A. Factors underlying residential radon concentration: results from Galicia, Spain. Environ Res 2007; 103:185-90.

6. U.S. Environmental Protection Agency. A citizen's guide to radon. The guide to protecting yourself and your family from radon. http://www2.epa.gov/sites/production/ files/2015-05/documents/citizensguide.pdf (accessed on 10/Nov/2015). 
7. Laboratorio de Radón de Galicia. Tablas de medición. http://www.usc.es/radongal/ra don-en-galicia/tablas-de-medicions/ (accessed on 10/Nov/2015).

8. Ruano-Ravina A, Quindós-Poncela L, Sainz Fernández C, Barros-Dios JM. Radón interior y salud pública en España. Tiempo para la acción. Gac Sanit 2014; 28:439-41.

9. Ruano-Ravina A, Rodríguez MC, CerdeiraCaramés S, Barros-Dios JM. Residential radon and lung cancer. Epidemiology 2009; 20:155-6.

10. Barbosa-Lorenzo R, Ruano-Ravina A, Cerdeira Caramés S, Barros-Dios JM. Radón residencial y cáncer de pulmón: un estudio ecológico en Galicia. Med Clin (Barc) 2015; 144:304-8.

11. Barros-Dios JM, Ruano-Ravina A, Pérez-Ríos M, Castro-Bernárdez M, Abal-Arca J, TojoCastro M. Residential radon exposure, histologic types, and lung cancer risk: a case-control study in Galicia, Spain. Cancer Epidemiol Biomark Prev 2012; 21:951-8.

12. Gutierrez-Villanueva JL, Sainz-Fernández C, Fuente-Merino I, Sáez-Vergara JC, CorreaGarcés E, Quindos-Poncela LS. Intercomparison exercise on external gamma dose rate under field conditions at the laboratory of natural radiation (Saelices el Chico, Spain). Radiat Prot Dosimetry 2013; 155:459-66.

13. Vargas A, Ortega X. Influence of environmental changes on continuous radon monitors: results of a Spanish intercomparison exercise. Radiat Prot Dosimetry 2006;121:303-9.

14. Vargas A, Ortega X. Influence of environmental changes on integrating radon detectors: results of an intercomparison exercise. Radiat Prot Dosimetry 2007; 123:529-36.

15. Turner MC, Krewski D, Chen Y, Pope CA, Gapstur S, Thun MJ. Radon and lung cancer in the American Cancer Society cohort. Cancer Epidemiol Biomarkers Prev 2011; 20:438-48.

16. Bräuner EV, Andersen CE, Sørensen M, Jovanovic Andersen Z, Gravesen P, Ulbak K, et al. Residential radon and lung cancer incidence in a Danish cohort. Environ Res 2012; 118:130-6.
17. Tomásek L, Kunz E, Müller T, Hůlka J, Heribanová A, Matzner J, et al. Radon exposure and lung cancer risk: Czech cohort study on residential radon. Sci Total Environ 2001; 272:43-51.

18. Torres-Durán M, Ruano-Ravina A, ParenteLamelas I, Leiro-Fernández V, Abal-Arca J, Montero-Martínez C, et al. Lung cancer in never-smokers: a case-control study in a radon-prone area (Galicia, Spain). Eur Respir J 2014; 44:994-1001.

19. Darby S, Hill D, Auvinen A, Barros-Dios JM, Baysson H, Bochicchio F, et al. Radon in homes and risk of lung cancer: collaborative analysis of individual data from 13 European case-control studies. BMJ 2005; 330:223.

20. Krewski D, Lubin JH, Zielinski JM, Alavanja M, Catalan VS, Field RW, et al. Residential radon and risk of lung cancer: a combined analysis of 7 North American case-control studies. Epidemiology 2005; 16:137-45.

21. Ruano-Ravina A, Faraldo-Valles MJ, BarrosDios JM. Is there a specific mutation of p53 gene due to radon exposure? A systematic review. Int J Radiat Biol 2009; 85:614-21.

22. Ruano-Ravina A, Pérez-Becerra R, Fraga M, Kelsey KT, Barros-Dios JM. Analysis of the relationship between p53 immunohistochemical expression and risk factors for lung cancer, with special emphasis on residential radon exposure. Ann Oncol 2008; 19:109-14.

23. Ruano-Ravina A, Pereyra MF, Castro MT, Pérez-Ríos M, Abal-Arca J, Barros-Dios JM. Genetic susceptibility, residential radon, and lung cancer in a radon prone area. J Thorac Oncol 2014; 9:1073-80.

24. Barros-Dios JM, Barreiro MA, Ruano-Ravina A, Figueiras A. Exposure to residential radon and lung cancer in Spain: a population-based case-control study. Am J Epidemiol 2002; 156:548-55. 


\section{Resumen}

Los estudios de casos y controles muestran una asociación entre el radón residencial y el cáncer de pulmón. El objetivo del artículo fue investigar esa asociación a través de un estudio de cohorte. Proyectamos un estudio de cohorte ambispectivo, utilizando el mapa de radón de Galicia, España, con los controles obtenidos de un estudio anterior de casos y controles. Los individuos fueron reclutados entre 2002 y 2009. Los datos fueron verificados para confirmar la incidencia de cáncer de pulmón $y$ después analizados con un modelo de regresión de Cox. Participaron un total de 2.127 individuos; se identificaron 24 casos de cáncer de pulmón; un $76,6 \%$ de los individuos fueron obtenidos a través del mapa de radón. El hazard ratio ajustado era 1,2 (IC95\%: 0,5-2, 8) para la categoría de individuos expuestos a $50 \mathrm{~Bq} / \mathrm{m}^{3}$ o más. El riesgo aumentó cuando los individuos del estudio de casos $y$ controles fueron analizados separadamente. En conclusión, no se observó una asociación estadisticamente significativa entre exposición al radón residencial y cáncer de pulmón; sin embargo, parece que con una muestra con una media de edad más elevada (tales como los participantes del estudio de casos y controles), el riesgo de cáncer de pulmón habría sido más alto.

Radón; Carcinógenos Ambientales; Exposición a la Radiación; Neoplasias Pulmonares

\section{Resumo}

Estudos de casos e controles mostram uma associação entre radônio residencial e câncer de pulmão. $O$ artigo teve como objetivo investigar essa associação através de um estudo de coorte. Projetamos um estudo ambispectivo coorte, utilizando o mapa de radônio da Galícia, Espanha, com os controles obtidos de um estudo anterior de casos e controles. Os individuos foram recrutados entre 2002 e 2009. Os dados foram verificados para confirmar a incidência de câncer de pulmão e depois analisados com um modelo de regressão de Cox. Participaram um total de 2.127 individuos; foram identificados 24 casos de câncer de pulmão; 76,6\% dos indivíduos foram obtidos através do mapa de radônio. $O$ hazard ratio ajustado era 1,2 (IC95\%: 0,5-2,8) para a categoria de indivíduos expostos a $50 \mathrm{~Bq} / \mathrm{m}^{3}$ ou mais. O risco aumentou quando os indivíduos do estudo de casos e controles foram analisados separadamente. Em conclusão, não foi observada associação estatisticamente significativa entre exposição ao radônio residencial e câncer de pulmão; entretanto, parece que com uma amostra com mediana de idade mais elevada (tais como os participantes do estudo de casos e controles), o risco de câncer de pulmão teria sido mais alto.

Radônio; Carcinógenos Ambientais; Exposição à Radiação; Neoplasias Pulmonares
Submitted on $17 /$ Nov/2015

Final version resubmitted on $20 / \mathrm{Jul} / 2016$ Approved on 28/Jul/2016 